\title{
How rationality predicts individual perception of safety climate: An application of the hybrid model of learning in personality
}

\author{
Martina Dwi Mustika, ${ }^{1 *}$ Chris J. Jackson ${ }^{2}$ \\ ${ }^{1}$ Faculty of Psychology, Universitas Indonesia, Depok - Indonesia, ${ }^{2}$ UNSW Business School, the University of \\ New South Wales, Sydney - Australia
}

\begin{abstract}
Jackson's Hybrid Model of Learning in Personality (HMLP) is designed to measure the effect of biological, socio-cognitive, and experiential processes of personality and learning mechanisms on developing rationality and directing functional or dysfunctional behaviors of employees. We use HMLP to determine if rational thinking predicts individual perception of safety climate. The results found that the proposed indirect paths of learning mechanisms significantly predict the individual perception of a safety climate through rationality. The goodness-of-fit demonstrated that the model provided a satisfactory fit: $\chi^{2}=13.200, p=.067$; RMS $=$ .000 ; RMSEA $=.063 ; \mathrm{GFI}=.981 ; \mathrm{AGFI}=.943$; and $\mathrm{CFI}=.988$. As a result, we identify the importance of rationality in predicting individual safety climate and once again confirm the usefulness of HMLP in predicting useful workplace outcomes. The HMLP offers valuable insights into the influence of rationality in predicting individual perception of safety climate, as well as the underlying process of developing rationality.
\end{abstract}

Keywords: The Hybrid Model of Learning in Personality; HMLP; individual safety climate; Learning Style Profiler; rationality personality

\begin{abstract}
Abstrak: Jackson's Hybrid Model Learning in Personality (HMLP) dirancang untuk mengukur efek proses biologis, sosio-kognitif, dan pengalaman dari kepribadian dan mekanisme pembelajaran pada pengembangan rasionalitas dan mengarahkan perilaku fungsional atau disfungsional. Kami menggunakan HMLP untuk menentukan apakah pemikiran rasional memprediksi persepsi individu tentang iklim keselamatan. Hasil penelitian menemukan bahwa jalur tidak langsung yang diusulkan dari mekanisme pembelajaran secara signifikan memprediksi persepsi individu tentang iklim keselamatan melalui rasionalitas. Goodness-of-fit menunjukkan bahwa model memberikan kesesuaian yang memuaskan: $\chi^{2}=13,200, p=0,067$; RMS $=0,000$; RMSEA =0,063; GFI =0,981; AGFI =0,943; dan CFI =0,988. Sebagai hasilnya, kami mengidentifikasi pentingnya rasionalitas dalam memprediksi iklim keselamatan individu dan sekali lagi mengkonfirmasi manfaat HMLP dalam memprediksi hasil yang berguna di tempat kerja. HMLP menawarkan wawasan berharga tentang pengaruh rasionalitas dalam memprediksi persepsi individu tentang iklim keselamatan, serta proses yang mendasari pengembangan rasionalitas.
\end{abstract}

Kata Kunci: model hybrid pembelajaran dalam kepribadian; HMLP; iklim keselamatan individu; Learning Style Profiler; rasionalitas *Corresponding Author: Martina Dwi Mustika (martinadwimustika@gmail.com). Faculty of Psychology, Universitas Indonesia.
Kampus Baru, Depok 16424-Indonesia. 


\section{Introduction}

Previous research has emphasized the role of personality in predicting safety-related attitudes in organizational settings (Beus et al., 2015; Cellar et al., 2002; Kotzé \& Steyn, 2013; Neal \& Griffin, 2004; Stuhlmacher \& Cellar, 2002; Wallace \& Vodanovich, 2003). However, according to Clarke and Robertson (2008) and Christian, Bradley, Wallace anf Burke (2009), most studies have only examined one facet of personality when analyzing the relationship between safety behaviors and predicting safety outcomes, rather than two or more facets. It was because they tried to investigate how each facet of personality, such as extraversion, agreeableness, etc. influenced safety behaviors. In this study, we use Jackson's (2008) hybrid model of learning in personality (HMLP) to predict safety-related perceptions and attitudes in organizational settings. HMLP is a relatively new process model of learning that argues high performance has a basis in biological, cognitive, and experiential traits of personality (Jackson, 2008).

Perceptions and attitudes toward safety have been studied to investigate safety climates in organizational settings (James \& Jones, 1974; Williamson et al., 1997; Zohar, 1980). A safety climate is defined as "a concept describing the safety ethic in an organization or workplace which is reflected in employees' belief about safety and is thought to predict the way employees behave concerning safety in the workplace" (Williamson et al., 1997). Williamson et al. (1997) also argued that there are four individual factors related to promoting individual safety behaviors in organizations: motivations for safe behavior, risk justification, fatalism, and optimism. These factors help determine whether workers should receive certain support from management and adequate safety training and equipment to behave safely. We argue that these factors are likely to be predicted by personality because they assess how an individual behaves to promote a safety climate.

Previous studies argued that individuals must be rational and realistic to be functional (Dryden \& Neenan, 2004; Jackson et al., 2012). Rationality is defined as the cognitive expression of the basic willingness to accept an unwanted outcome of reality related to one's striving to achieve or block something, independent of how much it deviates from what one wants and independent of how strong one's desire is (DiGiuseppe et al., 2014).

Rational people possess the following four characteristics of belief: preferences, "antiawfulizing", high frustration tolerance (HFT), and unconditional self-acceptance. In contrast, irrational people possess the following characteristics: demanding, awfulizing, low frustration tolerance, and conditional self-acceptance to others and their life (DiGiuseppe et al., 2014). Moreover, a person with a high level of rationality controls his or her emotions, logic, and objectives, and employs learning patterns in stressful or dangerous situations (Jackson, 2005, 2008; Jackson et al., 2009). Therefore, rational people: a) have a positive attitude that helps them have positive objectives (preferences); b) can control emotions and overcome frustrations and the discomfort of negative or "bad" events or situations (antiawfulizing); c) have a high level of commitment and persistence to employ learning patterns (HFT), and as a result of d) can evaluate the available information about an event or situation in an attempt to ensure useful behavior in the future (unconditional self-acceptance).

We believe that rationality helps people obtain a positive perception of safety climate, 
leading to an overall safety climate in their organizations. We suggest that people with a high level of rationality are likely to have realistic, unconditional, and independent views of the appropriate support, training, and safety equipment provided by organizations to encourage safe behavior. This is because rational people have the ability to control and manage discomfort and their environment consistently. Rational people are also more likely to behave safely, even when appropriate safety equipment or training is not available. They will remain focused on high performance by evaluating their previous behavior, including consulting available information on events and situations to ensure they behave safely in the future. If no adequate safety support is available, rational people are likely to be motivated and hold positive attitudes toward managing and maintaining safety behaviors independently of their organization's commitment, because they think and behave unconditionally and independently. We predict that if rational people behave unsafely, they will be able to overcome such behavior and not blame others for their actions. Therefore, the following hypothesis is suggested:

H1: Rationality positively relates to individual perception of safety climate.

The cognitive, emotional, and behavioral factors of personality also influence rationality (Dryden \& Neenan, 2004; Ellis, 2004, 2017). Jackson's HMLP explains the development and maintenance of rationality as influenced by the biological, socio-cognitive, and experiential factors of personality (Jackson, 2005). The model has predicted organizational, educational, and clinical outcomes (Gardiner \& Jackson, 2012, 2015; Jackson, 2005, 2008, 2009; Jackson et al., 2012). Specifically, the Jackson et al. (2012) study deepened the model's ability to explain the development and maintenance of rationality by examining learning and personality antecedents of clinical depression in a sample of patients. HMLP comprises five personality characteristics: sensation seeking, mastery, deep learning, conscientiousness, and rationality. In this model, Jackson suggests that the individual's biological drive is measured through sensation seeking, while mastery and conscientiousness assess higher cognitive function developments that lead to better rationality. We use HMLP to investigate the antecedents of rationality and how rationality supports the development of a positive individual perception of safety climate in organizations.

Sensation seeking provides a need for stimulation and the desire to find and explore new learning experiences. High levels of curiosity drive this desire, and they remain relatively stable and unchanged over time (Jackson, 2005). It has overlaps in definition with Zuckerman's (1994) research on sensation seeking which is widely regarded as having a biological basis. As the most distal trait in the model, sensation seeking is believed to drive behavior toward both functional and dysfunctional outcomes (Jackson, 2011a; Jackson et al., 2012). To direct behavior toward functional outcomes, sensation-seeking should be re-expressed through the learning mechanisms of mastery orientation, conscientiousness, and deep learning, which lead to the development of rationality (Jackson, 2008, 2009; Jackson et al,, 2012). Therefore, we suggest four possible indirect paths from sensation seeking to rationality (see Figure 1). Sensation seeking can be re-expressed through mastery orientation to rationality; mastery orientation to conscientiousness to rationality; deep learning to rationality; and deep learning to conscientiousness to rationality. The paths are not new to the literature and have been tested multiple 
times in the past such as by Gardiner and Jackson $(2012,2015)$ and Jackson et al. (2012). Each path is discussed as the hypotheses are developed.

Mastery orientation is a tendency to achieve success in learning by focusing effort and attention to master problems, and employing high levels of self-efficacy and self-confidence so that specific, difficult, and challenging goals are achieved (Jackson, 2005). Focus on goal achievement develops the cognitive skills of rationality, specifically through reducing frustration, engendering a more positive attitude, and recognizing that independently allocating effort leads to success. (Bjørnebekk \& Diseth, 2010; Elliot \& Thrash, 2002, 2010) argue that mastery re-directs biologically based approach drives which provides support for a link between sensation seeking and mastery. In this first path, we suggest that sensation seeking predicts perception of the safety climate for the individual through an indirect path of mastery orientation and rationality. Curious and exploratory people able to focus on developing their effort and attention will also develop positive rational attitudes toward their perception of safety climate because they have a high level of selfefficacy and self-confidence, enabling them to believe they can tackle problems.

This study also argues that the indirect path from sensation seeking to mastery orientation is better able to predict the individual perception of safety climate if the behaviors resulting from curiosity and mastery orientation are responsible and persistent (Jackson et al., 2009). Responsibility and persistence are characteristics of a conscientious individual. In HMLP, an individual who achieves high scores on the conscientiousness scale is considered responsible, wise, methodical, insightful, constructive, persistent, and able to learn complex rules to develop responsibility and conscientiousness (Jackson et al., 2009). Conscientiousness, responsibility, and persistence are important in helping individuals explore their environment, use their energy to master problems using complex resources and focus their attention

Figure 1

Indirect Path of the Hybrid Model of Learning in Personality in Predicting Individual Perception of Safety Climate

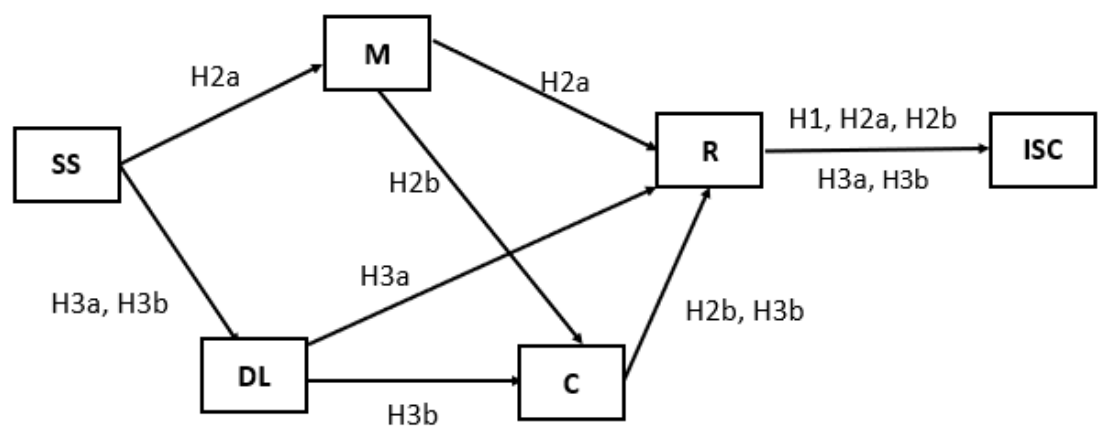

$\mathrm{SS}=$ sensation seeking, $\mathrm{R}=$ rationality, $\mathrm{M}=$ mastery orientation $\mathrm{C}=$ conscientiousness, $\mathrm{DL}=$ deep learning, ISC = individual perception of safety climate. 
to achieving goals (Jackson et al., 2012). This leads to rationality, so an individual will have reduced frustration, a more positive attitude, and recognition that independently allocating effort leads to a positive individual perception of safety climate. Therefore, this paper makes the following hypotheses:

H2a: Sensation seeking predicts individual perception of safety climate through mastery orientation and rationality.

H2b: Sensation seeking predicts individual perception of safety climate through mastery orientation, conscientiousness, and rationality.

In addition to rationality, mastery orientation, and conscientiousness, HMLP proposes an indirect path that involves reflecting and learning (Jackson et al., 2009). Deep learners hone their curiosity from sensation seeking to understand their environment profoundly to be functional. In HMLP, a deep learner is defined as a reflective individual with a love of learning (Jackson, 2005). Curiosity and drive from sensation seeking can be directed toward this deep love of learning, which helps individuals have a positive orientation to their environment, specifically because they can reflect, evaluate, and ensure their behaviors are positive and appropriate. Further, the willingness to learn how things work helps individuals align their behavior with their environment (Jackson et al., 2009, 2012). These evaluative plans and their implementation should be enough to develop rationality. As a result, individuals with such characteristics are more likely to find new methods of promoting and creating better and more practical safety behaviors in many situations. They are also more likely to possess a high level of awareness required to maintain positive safety perception, even when appropriate organizational support is not available.
However, although deep learners show features that promote rationality (such as reflection, evaluative skills, and enjoying learning), we argue that those characteristics could also result in irrationality. For example, if an individual evaluated an emergency too much, they may end up taking an inappropriate approach as it may be too late to execute it. Jackson (Jackson, 2005) suggested an individual who puts too much effort into learning and reflection may disrupt others. In practical situations, being too reflective and evaluative may result in unrealistic and inexpedient behaviors (Jackson, 2005). Consequently, we suggest that practicality, which is typically present at low levels in deep learners, is more appropriate to developing rationality and in predicting individual perception of safety climate.

Developing better rationality is also beneficial if behaviors resulting from planning and reflecting are persistent and responsible. This persistence and commitment to behaving effectively and positively lead individuals to perform useful behavior and maintain their hard work in the future (Jackson et al., 2009, 2012). Positive and effective actions also reflect unconditional selfacceptance, one of the characteristics of rational people. This leads to a positive individual perception of safety climate. Therefore, this study suggests that conscientiousness needs to be part of the relationship of sensation seeking to deep learning and rationality. This is expressed as:

H3a: Sensation seeking predicts individual perception of safety climate through deep learning and low rationality.

H3b: Sensation seeking predicts individual perception of safety climate through deep learning, conscientiousness, and rationality.

This study analyses all hypotheses using one model. The model investigates how rationality is developed and maintained in predicting individual 
perception of safety climate. It is important to investigate the influence of individual characteristics in developing and maintaining rationality, as it provides a better understanding of the relationship. Further, it would benefit understanding rationality's importance in promoting a positive individual perception of safety climate.

\section{Method}

\section{Participants and Procedures}

This study included 118 females $\left(\mathrm{M}_{\mathrm{Age}}=\right.$ 30.31, $\mathrm{SD}_{\text {Age }}=8.50$ ) and 108 males $\left(\mathrm{M}_{\mathrm{Age}}=30.33, \mathrm{SD}_{\mathrm{Age}}=6.29\right)$ employees. Participant selection was based on completion of the Learning Style Profiler which is used to measure HMLP and an organizational safety climate questionnaire. All participants responded to the questionnaires using YWeDO-a cognitive online laboratory (Jackson, 2011b). Fraser and Boag (2010) compared the use of online and face-to-face data; their valuable results support this study. They compared participants' performance during a face-to-face, evaluative presence with online data, and found that performance was not significantly different. Further, no evidence assessing performance via online data collection was less accurate than face-to-face data collection.

\section{Materials}

The hybrid model of learning in personality (HMLP). This study used Jackson's (2008) Learning Style Profiler to measure sensation seeking, rationality, mastery orientation, deep learning, and conscientiousness. This profiler contains 75 items and examples of the questions include: "I have new ideas all the time" (sensation seeking); "I often feel that I have little influence over things that happen to me" (rationality); "I achieve specific goals that I set myself" (mastery); "I consider it extremely important to have regular dental check-ups" (conscientiousness); "I frequently pause just to meditate about things in general" (deep learning).

\section{Individual perception of safety climate.}

The study used the 21 items from Williamson et al.'s (1997) study to measure the individual perception of safety climate. Thus, the following four factors were assessed: personal motivation for safe behavior, risk justification, fatalism, and optimism, as they concern safety from the respondents' perspective. Examples of questions include: "When I have worked unsafely, it has been because I was not trained properly"; "I cannot avoid taking risks in my job"; "Not all accidents are preventable - I am just unlucky". The first eight items were categorized using a five-point scale (1 $=$ "never" to $5=$ "always"), and the remaining items were categorized according to a different five-point scale $(1=$ "strongly disagree" to $5=$ "strongly agree"). The total score was obtained by adding all item scores.

\section{Data Analysis}

Similar to previous studies that used HMLP (Jackson et al, 2009, 2012), the current study employed path analysis to analyze the suggested indirect path model and used bootstrap to assess the model's significance.

\section{Results}

Means, standard deviations, correlations, and scale reliability results are presented in Table 1 , which shows, as could be expected, that most of the learning and personality variables correlated positively and significantly with each other (ranging between 0.276 and 0.743). However, rationality did not correlate significantly with sensation seeking and deep learning $(r=0.115$, n.s 
and $r=-.094$, n.s, respectively). Additionally, only rationality $(\mathrm{r}=.217, \mathrm{p}<.05)$ correlated significantly with individual perception of safety climate. Table 1 also shows that all HMLP scales and perceptions of individual safety climate had reliable internal consistency (all above $\alpha=.70$ ).

All standardized regression estimates (see Figure 2) were significant. These results support this study's hypotheses. The goodness-of-fit results also demonstrated that this study's model provided a satisfactory fit: $\chi^{2}=13.200, \mathrm{p}=.067$ (Hayakawa, 2019; Hu \& Bentler, 1999); rootmean-square residual $=.000$ (Hayakawa, 2019;
Hu \& Bentler, 1999); root mean-square error of approximation $=.063$ (Browne, M. W. \& Cudeck, 1993; Marsh et al., 2005); goodness-of-fit index = .981 (Jöreskog \& Sörbom, 1996); adjusted goodness-of-fit index $=.943$ (Jöreskog \& Sörbom, 1996); and comparative-fit index $=.988$ (Bentler, 1990; Marsh et al., 2005). All hypothesized paths were significant, and therefore all hypotheses were supported. Additionally, the standardized indirect effect from sensation seeking to individual perception of safety climate was significant ( $\mathrm{p}<$ .05 ; bias-corrected, two-tailed significance).

Table 1

Means, Standard Deviations, Correlations, and Scale Reliabilities

\begin{tabular}{|c|c|c|c|c|c|c|c|c|}
\hline & Mean & SD & SS & $\mathrm{R}$ & M & $\mathrm{C}$ & DL & ISC \\
\hline SS & 22.81 & 6.15 & .81 & & & & & \\
\hline $\mathrm{R}$ & 22.68 & 6.18 & .115 & .79 & & & & \\
\hline M & 18.89 & 6.96 & $.743^{* *}$ & $.283^{* *}$ & .81 & & & \\
\hline $\mathrm{C}$ & 19.61 & 6.06 & $.580^{* *}$ & $.276^{* *}$ & $.713^{* *}$ & .83 & & \\
\hline DL & 22.58 & 6.49 & $.604^{* *}$ & -.094 & $.517^{* *}$ & $.469^{* *}$ & .73 & \\
\hline ISC & 57.81 & 11.79 & $.181^{* *}$ & $.217^{*}$ & $.200^{* *}$ & $.173^{* *}$ & .015 & .83 \\
\hline
\end{tabular}

$\mathrm{SS}$ = sensation seeking, $\mathrm{R}=$ rationality, $\mathrm{M}=$ mastery orientation, $\mathrm{C}=$ conscientiousness,

$\mathrm{DL}=$ deep learning, ISC = individual perception of safety climate.

Note. * Correlation is significant at the .05 level (two-tailed).

** Correlation is significant at the .01 level (two-tailed).

Diagonal entries are scale reliabilities.

\section{Discussion}

This study investigated how the HMLP predicts individual perception of safety climate based on three main hypotheses derived from previous studies that have also focused on the importance of rationality (Jackson et al., 2009, 2012). We argued that rational individuals would have a positive individual perception of safety climate because they can re-express their biological drive of sensation seeking through a series of learning mechanisms that lead to functional learning. Path analysis provided support for our hypotheses.

In support of $\mathrm{H} 1$, the results showed a positive and significant relationship between rationality and individual perception of safety climate. Our research suggests rational and realistic individuals have a positive preference toward safety ethics within organizations, influencing their safety actions and behaviors and the ways they evaluate 
Figure 2

Standardized Regression Estimates for Indirect Paths of the Hybrid Model of Learning in Personality in Predicting Individual Perception of Safety Climate
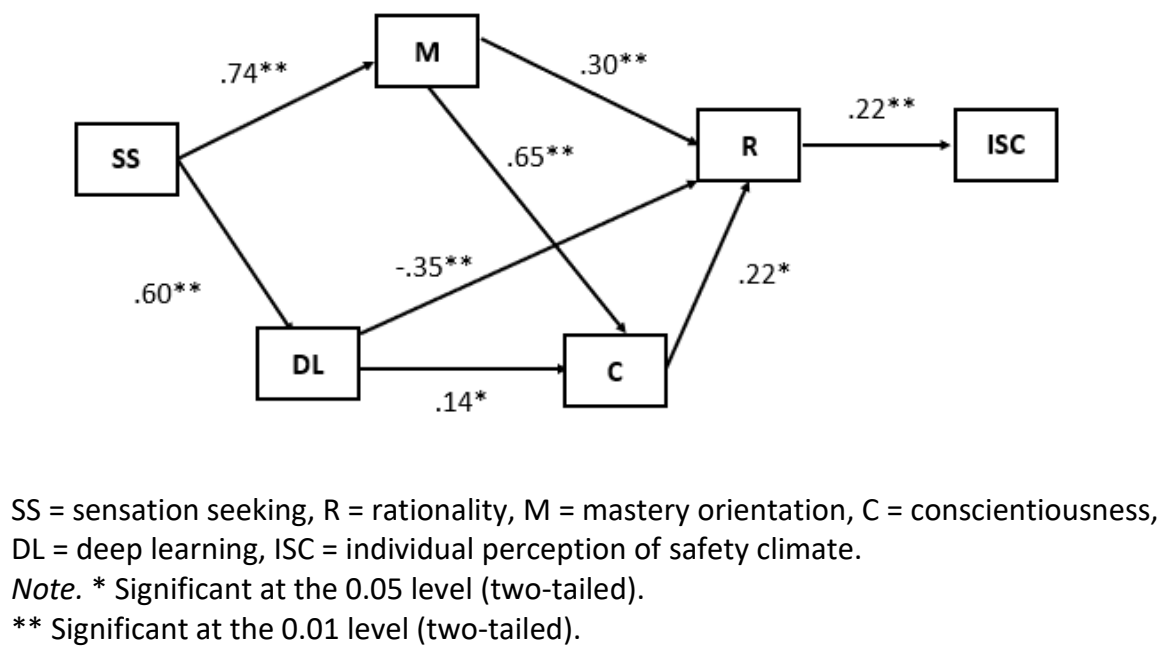

available support, training, and safety equipment encouraging safety behavior for themselves and others in their organization. Rational individuals also possess unconditional self-acceptance, enabling them to believe in themselves and their previous learning and evaluation regarding safety, thereby making them committed to behaving safely in their organization. Further, rational individuals are more likely to support safety in their environment, and their awareness of unsafe behaviors leads them to behave more safely, particularly after having experienced an unsafe situation. Finally, these individuals can control their emotions, logic, and objectives (Jackson, 2008) when facing unsafe situations, and overcome their frustration when there are no appropriate supports for safety behaviors. The organization should develop and maintain workers' rationality so that employees can consistently behave safely, even if safety support from the organization is not always available. Accordingly, knowing how rationality can be developed and maintained is important, and the hybrid model of learning in personality provides a model explaining this.

As proposed by $\mathrm{H} 2 \mathrm{a}$ and $\mathrm{H} 2 \mathrm{~b}$, mastery orientation directs curiosity and exploratory traits of sensation seeking to master a problem, which encourages an individual to put effort into achieving goals, behaving functionally, and developing self-confidence and self-efficacy (Jackson et al., 2009, 2012). Confidence and belief in one's ability to solve and master problems develop a high level of rationality, leading to high individual perception of safety climate. Mastery provides effort and self-efficacy which fosters assessment of safety-related behaviors as appropriate and functional. Moreover, with the help of conscientiousness, individuals can see problems more rationally, as they are more persistent and committed to solving problems and achieving future success (Jackson et al., 2009, 2012).

Further, as suggested by $\mathrm{H} 3 \mathrm{a}$ and $\mathrm{H} 3 \mathrm{~b}$, curiosity from sensation-seeking can promote a 
love of learning, encouraging individuals to reflect on their learning behaviors to adapt to situations by finding ways of tackling similar problems in the future. However, in some situations, deep learners may pay too much attention to their learning and disrupt others, particularly when trying to implement practical plans (Jackson, 2005). Such behavior may render some deep learners unrealistic and inexpedient when tasked with selecting appropriate future actions designed to be effective and functional. As been explained in the introduction, an action may need faster response or evaluation. Therefore, that action can be executed to tackle a problem. This explains why the relationship between deep learning and rationality was negative. The indirect path analysis through conscientiousness also showed that self-confidence and self-efficacy help deep learners develop their rationality. Thus, this study argued that conscientious characteristics are required by deep learners, to help re-express their curiosity and direct their learning reflection to develop their rationality. As a result, these individuals will develop the positive individual perception of safety climate because they can reflect on the necessity of safety support from their organization, so that they may not rely too much on the organization to maintain their safety behaviors.

This study shows HMLP, as a multi-trait process model, predicts individual perception of safety climate. In contrast to other models of personality in which traits are usually analyzed separately, HMLP proposes that multiple personality characteristics can jointly influence perceptions, attitudes, and behaviors (Colbert et al., 2004; Lim et al., 2016; Sackett et al., 1998; Witt et al., 2002). This study also provides additional support for the HMLP as a general predictor of workplace performance and outcomes. It is suggested that functional performance has a partial basis in a mix of biological, socio-cognitive, and experiential processes of personality.

Similar to other studies, the cross-sectional self-report methodology does not address the effect of common method bias (Conway \& Lance, 2010; Spector, 1994). Moreover, the method cannot be used to explain cause and effect, as the data were taken at one point only (Mann, 2003). However, as this study sought to investigate the relationship between personality traits and individual perception of safety climate, this methodology was appropriate as it is hard to measure these variables using other techniques (Mann, 2003). In the future, other methods may be used to test the generalizability of our results (such as the use of objective measures, interviews, and observations), including the use of pre-post methods to investigate the differences between responses.

\section{Conclusion}

In short, the results of this study indicate that HMLP can explain the development and maintenance of rationality and that this is associated with a positive individual perception of safety climate. Consistent with previous research (Jackson, 2009; Jackson et al., 2009, 2012), this study also found that a high level of curiosity and exploration in sensation seeking can enable individuals to overcome problems, achieve complex goals and be reflective when re-expressed through mastery orientation, deep learning, and conscientiousness. These learning mechanisms then help develop and maintain rationality in perceiving individual perception of safety climate. Our research further demonstrates that the hybrid model of learning in personality is a useful predictor of individual perception of safety climate.] 


\section{References}

Bentler, P. M. (1990). Comparative fit indexes in structural models. Psychological Bulletin, 107(2), 238246. https://doi.org/10.1037/0033-2909.107.2.238

Beus, J. M., Dhanani, L. Y., \& McCord, M. A. (2015). A meta-analysis of personality and workplace safety: Addressing unanswered questions. Journal of Applied Psychology, 100(2), 481-498. https://doi.org/10.1037/a0037916

Bjørnebekk, G., \& Diseth, Å. (2010). Approach and avoidance temperaments and achievement goals among children. Personality and Individual Differences, 49(8), 938-943. https://doi.org/10.1016/j.paid.2010.07.034

Browne, M. W. \& Cudeck, R. (1993). Alternative ways of assessing model fit. In K. A. B. J. S. Long (Ed.), Testing Structural Equation Models (pp. 136-162). Sage Publication.

Cellar, D. F., Nelson, Z. C., Yorke, C. M., \& Bauer, C. (2002). The five-factor model and safety in the workplace: Investigating the relationships between personality and accident involvement. Journal of Prevention and Intervention in the Community, 22(1), 43-52. https://doi.org/10.1080/10852350109511210

Christian, M. S., Bradley, J. C., Wallace, J. C., \& Burke, M. J. (2009). Workplace safety: A meta-analysis of the roles of person and situation factors. Journal of Applied Psychology, 94(5), 1103-1127. https://doi.org/10.1037/a0016172

Clarke, S., \& Robertson, I. (2008). An examination of the role of personality in work accidents using meta-analysis. Applied Psychology, 57(1), 94-108. https://doi.org/10.1111/j.14640597.2007.00267.x

Colbert, A. E., Mount, M. K., Harter, J. K., Witt, L. A., \& Barrick, M. R. (2004). Interactive effects of personality and perceptions of the work situation on workplace deviance. Journal of Applied Psychology, 89(4), 599-609. https://doi.org/10.1037/0021-9010.89.4.599

Conway, J. M., \& Lance, C. E. (2010). What reviewers should expect from authors regarding common method bias in organizational research. Journal of Business and Psychology, 25(3), 325-334. https://doi.org/10.1007/s10869-010-9181-6

DiGiuseppe, R. A., Doyle, K. A., Drylen, W., \& Backx, W. (2014). A practitioner's guide to rational emotive therapy (3rd ed.). Oxford University Press.

Dryden, W., \& Neenan, M. (2004). The rational emotive behavioural approach to therapeutic change. SAGE Publications Ltd. https://doi.org/10.4135/9781446216750

Elliot, A. J., \& Thrash, T. M. (2002). Approach-avoidance motivation in personality: Approach and avoidance temperaments and goals. Journal of Personality and Social Psychology, 82(5), 804818. https://doi.org/10.1037/0022-3514.82.5.804

Elliot, A. J., \& Thrash, T. M. (2010). Approach and avoidance temperament as basic dimensions of personality. Journal of Personality, 78(3), 865-906. https://doi.org/10.1111/j.14676494.2010.00636.x

Ellis, A. (2004). Rational emotive behavior therapy: It works for me - it can work for you. Prometheus Books.

Ellis, A. (2017). Rational emotive behavior therapy. In Theoretical models of counseling and psychotherapy (pp. 311-335). Routledge. https://doi.org/10.4324/9781315733531-10 
Fraser, M., \& Boag, S. (2010). Social facilitation and performance: Comparing online to face-to-face testing. Paper Presented at the 9th Australian Conference on Personality and Individual Differences.

Gardiner, E., \& Jackson, C. J. (2012). Workplace mavericks: How personality and risk-taking propensity predicts maverickism. British Journal of Psychology, 103(4), 497-519. https://doi.org/10.1111/j.2044-8295.2011.02090.x

Gardiner, E., \& Jackson, C. J. (2015). Personality and learning processes underlying maverickism. Journal of Managerial Psychology, 30(6), 726-740. https://doi.org/10.1108/JMP-07-2012-0230

Hayakawa, K. (2019). Corrected goodness-of-fit test in covariance structure analysis. Psychological Methods, 24(3), 371-389. https://doi.org/10.1037/met0000180

Hu, L., \& Bentler, P. M. (1999). Cutoff criteria for fit indexes in covariance structure analysis: Conventional criteria versus new alternatives. Structural Equation Modeling: A Multidisciplinary Journal, 6(1), 1-55. https://doi.org/10.1080/10705519909540118

Jackson, C. J. (2005). An applied neuropsychological model of functional and dysfunctional learning: Applications for business, education, training and clinical psychology. Cymeon.

Jackson, C. J. (2008). Measurement issues concerning a personality model spanning temperament, character, and experience. In The SAGE Handbook of Personality Theory and Assessment: Volume 2 - Personality Measurement and Testing (pp. 73-94). SAGE Publications Ltd. https://doi.org/10.4135/9781849200479.n4

Jackson, C. J. (2009). Using the hybrid model of learning in personality to predict performance in the workplace. Paper Presented at the 8th IOP Conference.

Jackson, C. J. (2011a). How sensation seeking provides a common basis for functional and dysfunctional outcomes. Journal of Research in Personality, 45(1), 29-36. https://doi.org/10.1016/j.jrp.2010.11.005

Jackson, C. J. (2011b). Introducing the YWEDO online cognitive laboratory. In Personality and Individual Differences: Theory, Assessment, and Application (pp. 283-293).

Jackson, C. J., Baguma, P., \& Furnham, A. (2009). Predicting grade point average from the hybrid model of learning in personality: Consistent findings from Ugandan and Australian students. Educational Psychology, 29(7), 747-759. https://doi.org/10.1080/01443410903254583

Jackson, C. J., Izadikah, Z., \& Oei, T. P. S. (2012). Mechanisms underlying REBT in mood disordered patients: predicting depression from the hybrid model of learning. Journal of Affective Disorders, 139(1), 30-39. https://doi.org/10.1016/j.jad.2011.09.025

James, L. R., \& Jones, A. P. (1974). Organizational climate: A review of theory and research. Psychological Bulletin, 81(12), 1096-1112. https://doi.org/10.1037/h0037511

Jöreskog, K. G., \& Sörbom, D. (1996). LISREL 8: A guide to the program and applications (2nd ed.). SPSS.

Kotzé, M., \& Steyn, L. (2013). The role of psychological factors in workplace safety. Ergonomics, 56(12), 1928-1939. https://doi.org/10.1080/00140139.2013.851282

Lim, L. C., Teh, C. J., \& Benjamin, C. Y. F. (2016). A preliminary study of the effects of personality traits on workplace deviance in the voluntary sector. International Review of Management and Marketing, 6(7Special Issue), 6-10.

Mann, C. J. (2003). Observational research methods. research design II: Cohort, cross sectional, and casecontrol studies. Emergency Medicine Journal, 20(1), 54-60. https://doi.org/10.1136/emj.20.1.54 
Marsh, H. W., Hau, K.-T., \& Grayson, D. (2005). Goodness of fit in structural equation models. In A. Maydeu-Olivares \& J. J. McArdle (Eds.), Contemporary psychometrics: A festschrift for Roderick $P$. McDonald (pp. 276-335). Psychology Press. https://doi.org/10.4324/9781410612977

Neal, A., \& Griffin, M. A. (2004). Safety climate and safety at work. In J. B. \& M. R. Frone (Ed.), The psychology of workplace safety (pp. 15-34). American Psychological Association. https://doi.org/10.1037/10662-002

Sackett, P. R., Gruys, M. L., \& Ellingson, J. E. (1998). Ability-personality interactions when predicting job performance. Journal of Applied Psychology, 83(4), 545-556. https://doi.org/10.1037/00219010.83.4.545

Spector, P. E. (1994). Using self-report questionnaires in OB research: A comment on the use of a controversial method. Journal of Organizational Behavior, 15(5), 385-392. https://doi.org/10.1002/job.4030150503

Stuhlmacher, A. F., \& Cellar, D. F. (2002). The role of individual differences in understanding and predicting workplace safety. Journal of Prevention and Intervention in the Community, 22(1), 13.

Wallace, J. C., \& Vodanovich, S. J. (2003). Workplace safety performance: Conscientiousness, cognitive failure, and their interaction. Journal of Occupational Health Psychology, 8(4), 316-327. https://doi.org/10.1037/1076-8998.8.4.316

Williamson, A. M., Feyer, A. M., Cairns, D., \& Biancotti, D. (1997). The development of a measure of safety climate: The role of safety perceptions and attitudes. Safety Science, 25(1-3), 15-27. https://doi.org/10.1016/S0925-7535(97)00020-9

Witt, L. A., Burke, L. A., Barrick, M. R., \& Mount, M. K. (2002). The interactive effects of conscientiousness and agreeableness on job performance. Journal of Applied Psychology, 87(1), 164-169. https://doi.org/10.1037/0021-9010.87.1.164

Zohar, D. (1980). Safety climate in industrial organizations: Theoretical and applied implications. Journal of Applied Psychology, 65(1), 96-102. https://doi.org/10.1037/0021-9010.65.1.96

Zuckerman, M. (1994). Behavioral expressions and biosocial bases of sensation seeking. Cambridge University Press. 